\title{
Developing Speaking Skills through Reading
}

\author{
Çağrı Tuğrul Mart \\ Correspondence: Çağrı Tuğrul Mart, Department of Languages, Ishik University, Erbil, Iraq. Tel: \\ 964-750-308-61-22. E-mail: tugrulbey@hotmail.com
}

Received: October 17, 2012 Accepted: November 6, 2012 Online Published: November 29, 2012

doi:10.5539/ijel.v2n6p91 URL: http://dx.doi.org/10.5539/ijel.v2n6p91

\begin{abstract}
There is an increasingly high relationship between reading and speaking skills. There is no question that people who develop large reading vocabularies tend to develop large speaking vocabularies. Indeed, reading power relies on continuous improvement in vocabulary knowledge that provides communication. The importance of word knowledge, which facilitates speaking skills, has been a major resource in the development of reading skills. Therefore fostering improvement in word knowledge through wide reading has the potential for fostering improvement in speaking skills. This article focuses on how printed words relate to spoken words and finally how reading contributes to speech.
\end{abstract}

Keywords: reading skills, speaking skills, vocabulary knowledge

\section{Introduction}

"Where there is little reading there will be little language learning. ... the student who wants to learn English will have to read himself into a knowledge of it unless he can move into an English environment" (Bright and McGregor, 1970, p.52).

Language acquisition without reading is difficult. Reading is a good way of comprehension. A good reader is able to understand sentences and structures of a written text. Bright and McGregor are of the opinion that reading is 'the most pleasant route to command of the language', because it is via reading 'the student is most likely to find words used memorably with force and point.'(1970, p.53). It appears that reading is a key factor in language learning. One important notion of developing reading skills and speaking skills is to use the language for learning as well as communication. Reading can play a big part in successful language learning. It can develop speaking skills. It needs to be noted that speaking holds a very significant place in foreign language learning because through speech messages are conveyed. According to Ur (1996, p.120), "of all the four skills (listening, speaking, reading and writing), speaking seems intuitively the most important".

Reading outside the classroom is the most significant influence on oral communication ability. Students who read a lot are more likely to speak well. Students through reading develop in both fluency and accuracy of expression in their speaking. Davies and Pearse (2000) stresses the importance of communication as: "Real success in English teaching and learning is when the learners can actually communicate in English inside and outside the classroom."

\section{Speaking}

Speaking is being capable of speech, expressing or exchanging thoughts through using language. "Speaking is a productive aural/oral skill and it consists of producing systematic verbal utterances to convey meaning (Nunan, 2003, p.48)." (Harmer, 2001) notes down that from the communicative point of view, speaking has many different aspects including two major categories - accuracy, involving the correct use of vocabulary, grammar and pronunciation practised through controlled and guided activities; and, fluency, considered to be 'the ability to keep going when speaking spontaneously'. Bygate (1991, p.3), also emphasizes knowledge of the language, and skill in using this knowledge for an effective communication. Language knowledge and skill in using it, are considered two fundamental elements of an effective communication.

Among the elements necessary for spoken production, are the following (Harmer, 2001, p.269).

- Connected Speech: effective learners of English need to be able not only to produce the individual phonemes of English (as in saying I would have gone) but also to use fluent 'connected speech' as in (I'd 've gone). In connected speech sounds are modified, omitted, added or weakened. 
- Expressive Devices: native speakers of English change the pitch and stress of particular parts of utterances, vary volume and speed, and show by other physical and non-verbal means how they are feeling.

- Lexis and Grammar: spontaneous speech is marked by the use of number of common lexical phrases, especially in the performance of certain language functions.

- Negotiation and language: effective speaking benefits from the negotiatory language we use to seek clarification and to show the structure of what we are saying.

This study highlights vocabulary and grammar knowledge among these elements. Reading will enable learners to develop their vocabulary and grammar knowledge which will effectively contribute to their speaking skills. Vocabulary and grammar knowledge will enable learners to understand so reading will increase learners' understanding capability which they need for a better communication.

\section{Reading}

Reading is one of the most effective ways of foreign language learning. Reading simply is the interpretation of a written message. Walter R. Hill $(1979$, p.4) briefly defines reading as what the reader does to get the meaning he needs from contextual resources.

Reading is a fluent process of readers combining information from a text and their own background knowledge to build meaning and the goal of reading is comprehension (Nunan, 2003, p.68). The ability to read requires that the reader draw information from a text and combine it with information and expectations that the reader already has (Grabe, Stoller, 2001, p.187). Alderson J.C. (2000) states that reading is built from two components: word recognition and comprehension. These two components gained through reading will foster learners' language competence. Krashen and Terrell (1989, p.131) point out that reading enables learners to comprehend better which is an important factor that can develop language competence.

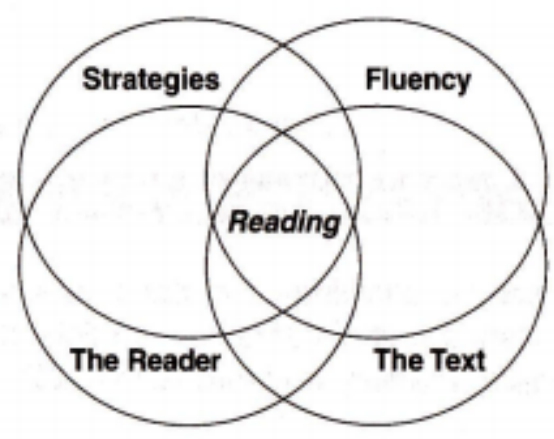

Figure 1. Definition of reading (David Nunan. Practical English Language Teaching. 2003. p. 72)

Hedge (2003) writes the goals of learners' in a reading process as:

- The ability to read a wide range of texts in English.

- Building a knowledge of language which will facilitate reading ability

- Building schematic knowledge

- The ability to adapt the reading style according to reading purpose (skimming, scanning)

- Developing an awareness of the structure of written texts in English

- Taking a critical stance to the contexts of the texts

Reading will add to learners' conversational performance. Reading will help learners to decipher new words that they need for conversations. Through reading language learners will have vocabulary knowledge which will facilitate their speaking performance and their usage of structure in the target language will develop. These components which are required through reading are all necessary for developing speaking skills. Similarly, Williams (1984, p.13) suggests some reasons why language learners should read in a foreign language:

- Learners can have further practice in the language that they have learnt,

- Learners can practice language in order to reuse it in other skills such as speaking and writing, 
- Learners can learn how to get benefit from the texts to extract the information they need,

- Learners can find enjoyment or interest through reading.

\section{Integrating Reading and Speaking Skills}

In a reading process six component skills have been suggested. Among these knowledge fields vocabulary and structural knowledge which are acquired through reading, influence learner's speaking achievement.

1) Automatic recognition skills

2) Vocabulary and structural knowledge

3) Formal discourse structure knowledge

4) Content/world background knowledge

5) Synthesis and evaluation skills/strategies

6) Metacognitive knowledge and skills monitoring (Grabe,1991, p.379).

How do these component skills contribute to speaking skills? Anne Lazaraton (2001, p.104) suggests that oral communication is based on four dimensions or competences: grammatical competence (phonology, vocabulary, word and sentence formation ...); sociolinguistic competence (rules for interaction, social meanings); discourse competence (cohesion and how sentences are liked together); and strategic competence (compensatory strategies to use in difficult strategies).

Vocabulary knowledge and grammar are two essential factors of foreign language learning, and they both influence learner's speaking performance. Good knowledge of grammar is viewed as an essential aspect for achievement in a foreign language. Grammar is important to learn the nature of language. Grammar helps learners to build comprehensible sentences in speaking. In order to understand how language works, learners should give attention to grammar. "If we only understand what others say partially and superficially, the communication of ideas can't be properly realized (Zhong-guo, Min-yan, 2007, p.63).” Reading will help learners acquire vocabulary and grammar. Through reading learners see how words fit together. When learners constantly engage in the target language, they begin noticing and mastering the patterns in the language. Mccarthy (2000) states that lexical and grammatical knowledge are significantly correlated to reading comprehension. This means learners will achieve better reading comprehension through grammar. Krashen (cited in Hill and Holden, 1990, p.92) encourages reading because it is a great factor in foreign language improvement and believes that students who read a lot are good at reading, good at writing and have a good vocabulary and grammar knowledge. Learners see structure of a sentence and this enables them to build their own sentences and utterances.

Reading may contribute significantly to competence in a second language. There is good reason, in fact, to hypothesize that reading makes a contribution to overall competence, to all four skills (Krashen \& Terrel, 1983, p.131)

Vocabulary knowledge is indispensable for effective communication. Lewis (1993, p.23) writes that learning vocabulary is the core task in second language learning and any language skills of listening, speaking, reading, writing, and translating cannot exist without vocabulary. Vocabulary is understanding the meaning of a word, so communication does not occur if there are no words. Therefore reading is probably the best way to learn new words. Reading results in incidental vocabulary acquisition (Lechmann, 2007). Nation supports this idea and says: "Reading has long been seen as a major source of vocabulary growth" (Nation, 1995, p.7). Most people recognize the important relationship between knowing words and reading well. Eskey, supporting this notion, states that "the relationship between reading and vocabulary is well documented and reciprocal" (Eskey, 2005, p.567). And, "in fact the relationship between vocabulary knowledge and reading comprehension is well established in the reading literature" (Dole, Sloan, Trathen, 1995, p.452). Hedge (1985, p.77) also states that through extensive reading learners advance their ability to of guessing the meanings of unknown words and phrases from clues in the context and he concludes that students who read a lot outside the classroom may increase both their comprehending the context and improving their vocabulary which are essential elements to advance speaking skills.

A broad and deep vocabulary knowledge makes learners precise and articulate. Through reading learners see how the new words connect to other words. "The more reading you will do, the more you will increase your exposure to vocabulary that doesn't usually make its way into the spoken language" (Cunningham, 1998). An improved vocabulary will help learners develop their speaking skills. Speech without vocabulary cannot be produced. Vocabulary is one of the essential and fundamental components of communication (Levelt, 1993). And 
Laufer (1997) stresses the importance of vocabulary knowledge and adds that without words to express a wider range of meaning, communication in a second language cannot happen in a meaningful way. Learners will improve their speaking competence if they have better vocabulary knowledge which they can get through reading.

Sanacore (1994, p.604), is of the opinion that encouraging learners to read will lead them guessing the meanings of words, phrases from the context, and the more they read the more they will understand the meanings of sentences and concepts. And an ongoing reading habit will enable learners understand a text easily, even they do not know meanings of some words in the text. Reading extensively will enhance their comprehension. Learners will easily comprehend in the foreign language if they advance their ability of guessing the meanings of words from context which will promote their speaking performance.

Dubin and Olshtain (1977, p.97) also point out that through extensive reading learners learn much vocabulary. They emphasize the benefits of extensive reading as:

- Students develop an ability to gain pleasure and also satisfaction from reading on their own in the language they are learning.

- They are exposed to the language in a more natural and less structured way. In other words, they get different unpressured feeling on the structure of the language since they read for pleasure, and not for a grade or a test.

- Extensive reading has also effect on other language skills such as writing and speaking.

- Extensive reading, or reading for pleasure, will help the students comprehend more and also continue to use the language after the instruction.

Oya, Manalo, and Greenwood suggest that better vocabulary knowledge produces better oral performance (2009, p.11). Accuracy and fluency of learners will get better through reading. They also claim that having good vocabulary knowledge is one of the essential components to gain fluency in speaking performance (Oya, Manalo, Greenwood, 2009, p.19). It needs to be noted that good vocabulary knowledge will give learners confidence in their speaking performance.

Better vocabulary knowledge and having more words at one's disposal is likely to facilitate the ability to tell a story better, to demonstrate a more extensive range of language resources, and to come across more intelligibly. Better vocabulary knowledge could also contribute to boosting the speaker's confidence, which would come across when speaking and influence the overall impression created. (Oya, Manalo, Greenwood, 2009, p.19)

In the theoretical model of L1 and L2 speaking (Levelt, 1989, 1993), vocabulary has a central position in forming an utterance with appropriate meanings and with syntactic, morphological, and phonological structures. Levelt's model suggests two points. First, vocabulary is always required in the formulation stage. In other words, no speech can be produced without vocabulary, and vocabulary is indispensable to speaking performance. Second, the lexicon consisting of lemmas and lexemes includes not only vocabulary size (i.e., primary meaning and form [phonology]) but also depth (i.e., syntax and morphology), which suggests that both size and depth are related to speaking performance (adapted from Rie Koizumi, 2005, p.53).

The study by Adams (1980) and Higgs and Clifford (1982) indicates close relationships between vocabulary as part of overall speaking performance and overall speaking performance at low levels than at intermediate and advance levels (adapted from Koizumi, 2005, p.53).

For spoken English the best reading materials are dramas, plays and dialogues. Learners have the opportunity to find sentences and phrases used in our daily conversation in dramas, plays and dialogues because they are all based on one person talking to another. Some studies have shown that using authentic texts has a positive effect on learning the target language by developing communicative competence (Peacock, 1997). "A text is usually regarded as authentic if it is not written for teaching purposes but for a real-life communicative purpose, where the writer has a certain message to pass on to the reader. As such, an authentic text is one that possesses an intrinsically communicative quality" (Lee, 1995). It is real language created by native speakers of the target language in pursuit of communicative outcomes (Little, Devitt, \& Singleton, 1989).

Integrating speaking and reading skills deepens students' understanding of the reading material, reveals any problem they have understanding a text, and, most importantly, lets them apply the information they have read into authentic speaking practice that improves their fluency (Zhang, 2009, p.34). 


\section{Conclusion}

Communication without vocabulary will break down. One of the most useful ways to improve your communication skills is extensive reading. Extensive reading will help you to develop your ability to express ideas, whilst also enlarging the size of vocabulary. Vocabulary knowledge is one of the crucial factors that will influence fluency in speaking. Reading introduces learners to a wider body of language and contexts. Reading helps learners build up better grammar skills. As learners develop stronger reading skills, they develop more sophisticated speaking skills.

\section{References}

Adams, M. L. (1980). Five coocurring factors in speaking proficiency. In J. R. Firth (Ed.), Measuring spoken language proficiency (pp. 1-6). Washington, DC: Georgetown University Press.

Alderson, J. C. (2000). Assessing Reading. Cambridge: Cambridge University.

Bright, J. A., \& G. P. McGregor. (1970). Teaching English as a Second Language. London: Longman.

Brusch, W. (1991). The role of reading in foreign language acquisition: Designing an experimental project. ELT Journal, 45(2), 156-163. http://dx.doi.org/10.1093/elt/45.2.156

Bygate, M. (1991). Speaking. Oxford: Oxford University Press.

Cunningham, A. E., \& Stanovich, K. E. (1998). What Reading does for the Mind. American Educator, 8(15).

Davies, P., Pearse, E. (2002). Success in English Teaching. Shanghai: Shanghai Foreign Language Education Press.

Dole, A. J., Sloan, C., \& Trathen, W. (1995). Teaching Vocabulary within the Context of Literature. Journal of Reading, 38(6), 452-460.

Dubin, F., \& Olshtain, E. (1977). Facilitating Language Learning: A Guidebook for the ESL/EFL Teacher. N.Y: McGrow: Hill International Book Company.

Eskey, D. (2005). Reading in a Second Language. In E. Hinkel (Ed), Handbook of research on second language teaching and learning (pp. 563-580). Mahvah, NJ: Lawrence Erlbaum.

Grabe, W. (1991). Current developments in second language reading research. TESOL Quarterl, 25(3), 375-406. http://dx.doi.org/10.2307/3586977

Grabe, W., \& Fredricka S. (2001). Reading for Academic Purposes Guidelines for the ESL/EFL Teacher. In M. Celce-Murcia (Ed.), Teaching English as a second foreign language. Boston: Heinle and Heinle.

Harmer, J. (2001). The Practice of English Language Teaching. Harlow: Pearson Education.

Hedge, T. (1985). Using Readers in Language Teaching. London: Macmillan Publishers Ltd.

Hedge, T. (2003). Teaching \& learning in the language Classroom. UK: OUP.

Higgs, T. V., \& Clifford, R. (1982). The push toward communication. In T. V. Higgs (Ed.), Curriculum, competence, and the foreign language teacher (pp. 57-79). Lincolnwood, IL: National Textbook.

Hill, D., \& Holden, S. (Eds). (1995). Language Teaching: 1988 Milan Conference Organized by the British Council. London: Modern English Publications.

Hill, W. R. (1979). Secondary School Reading: Process, Program, Procedure. Boston: Allyn and Bacon.

Krashen, S. D., \& Terrell, T. D. (1983). The Natural Approach: Language Acquisition in the Classroom. Oxford and San Francisco: Pergamon, Almany.

Krashen, S. D., \& Terrell, T. D. (1989). The Natural Approach: Language Acquisition in the Classroom. Pergamon: Prentice Hall.

Laufer, B. (1997). What is in a World That Makes it Hard to Easy: Some Intralexical Factors That Affect the Learning of Words. In N. Schmitt \& M. Maccarthy (Eds.), Vocabulary: Description, Acquisition and Pedagogy. Cambridge: Cambridge University Press.

Lazaraton, A. (2001). Teaching Oral Skills. In M. Celce-Murcia (Ed.), Teaching English as a second foreign language. Boston: Heinle and Heinle.

Lechmann, M. (2007). Is Intentional or Incidental Vocabulary Learning More Effective? Journal of foreign language teaching, 3(1), 23-28.

Lee, W. (1995). Authenticity Revisited: Text Authenticity and Learner Authenticity. ELT Journal, 49(4), 323-328. 
http://dx.doi.org/10.1093/elt/49.4.323

Levelt, W. J. M. (1989). Speaking: From intention to articulation. MA: MIT Press.

Levelt, W. J. M. (1993). The architecture of normal spoken language use. In G. Blanken, J. Dittmann, H. Grimm, J. C. Marshall, \& C. W. Wallesch (Eds.), Linguistic disorders and pathologies: An international handbook (pp. 1-15). Berlin: Walter de Gruyter.

Lewis, M. (1993). The Lexical Approach. London: Language Teaching Publications.

Li, Z., \& Song, M. (2007). The Relationship between Traditional English Grammar Teaching and Communicative Language Teaching. US-China Education Review, 4(1).

Little, D., Devitt, S., \& D. Singleton. (1989). Learning Foreign Languages from Authentic Texts: Theory and Practice. Dublin: Authentic in Association with CILT.

Mccarthy, F. (2000). Lexical and Grammatical Knowledge in Reading and Listening Comprehension by Foreign Language Learners of Spanish. Applied Language Learning, 2000(11), 323-348.

Nation, I. S. P. (1995-6). Best Practice in Vocabulary Teaching and Learning. EA Journal, 3(2), 7-15.

Nunan, D. (2003). Practical English Language Teaching. Boston: McGraw Hill.

Oya, T., Emmanuel M., \& Jackie G. (2009). The Influence of Language Contact and Vocabulary Knowledge on the Speaking Performance of Japanese Students of English. The Open Applied Linguistics Journal, 2009(2), 11-21. http://dx.doi.org/10.2174/1874913500902010011

Peacock, M. (1997). The Effect of Authentic Materials on the Motivation of EFL learners. ELT Journal, 51(2), 144-156. http://dx.doi.org/10.1093/elt/51.2.144

Rie, K. (2005). Relationships Between Productive Vocabulary Knowledge and Speaking Performance of Japanese Learners of English at the Novice Level. A Dissertation Submitted to the University of Tsukuba in Partial Fulfillment of the Requirements for the Degree of Doctor of Philosophy in Linguistics.

Sanacore, J. (1994). Lifetime Literacy through Independent Reading: The Principal is a Key Player. International Reading Association. Journal of Reading, 37(7), 602-606.

Schmitt, N. (2000). Vocabulary in language teaching. Cambridge University Press.

Ur, P. (1996). A Course in Language Teaching: Practice and Theory. Cambridge: Cambridge University Press.

Williams, E. (1984). Reading in the Language Classroom. London: Macmillan Publishers Ltd.

Zhang, Y. (2009). Reading to Speak: Integrating Oral Communication Skills. English Teaching Forum, 2009(1), 32-34. http://dx.doi.org/10.1061/41052(346)25 